"A new proof of the existence theorem for implicit functions," by G. A. Bliss; "On a set of kernels whose determinants form a Sturmian sequence," by $\mathrm{H}$. Bateman; "On the cubes of determinants of the second, third and higher orders," by R. E. Moritz; “Note on the maximal cyclic subgroups of a group of order $p^{m}$," by G. A. Miller; “An expression for the general term of a recurring series," by Tsuruichi Hayashi; "Shorter Notices": Lebon's Biographie et Bibliographie of Emile Picard and Paul Appell, by J. W. Young; Vermeintliche Beweise des Fermatschen Satzes, from the Archiv der Mathematik und Physik, and Lind's Ueber das letzte Fermatsche Theorem, by Joseph Lipke; Slaught and Lennes's Solid Geometry, by F. W. Owens, Hawkes, Luby and Touton's First Course in Algebra, by J. V. McKelvey; "Corrections"; "Notes"; "New Publications."

\section{WHEAT RUSTS AND SUNSPOTS}

In looking over a copy of the Journal of the Agri-Horticultural Society of Western India for April to June, 1906, I was interested to notice, on page 165 , an article with the above caption, by G. N. Sahasrabudhe, of the College of Agriculture at Poona. The author refers to a report in the Proceedings of the Australian Wheat Conferences of periodicity in the occurrence of Puccinia graminis in Australia. The years of the most severe attacks, it is stated, were 1867, 1878 and 1889, making a period of eleven years between every two maximum years. The writer goes on to state that this cycle suggested to some members of the conference that it had some relation with the various phases through which the fungus has to go, but quotes from Surgeon-Major D. Prain the statement that " the periodicity is not due to any inherent property of the fungus, but must, as seems to be the belief in Chili, be due to the recurrence of conditions favorable for its development." ${ }^{1}$ I quote the following paragraph entire:

We have trustworthy records of rust attacks in Australia from 1867. In that year it was almost

\footnotetext{
${ }^{1}$ Agri. Ledger, No. 16 of 1897, p. 9.
}

general and caused immense loss in South Australia. This is the minimum year of the sun-spot cycle (1867-78). The year 1878 was one of the worst years for rust in Victoria, and in South Australia it prevailed over a large area that year; that also was the minimum year of the sun-spot cycle. In South Australia 1880 was the year when a considerable area was affected; and it was the year when the sun-spot area was very small. The seasons 1882-1888 seem to have been very free from rust; and that was the maximum period of the sun-spot cycle (1879-1889). In 1889 it was almost general and caused great loss in South Australia, Victoria, New South Wales and Tasmania; and that was the minimum year of the sun-spots. This clearly proves that the attack of the pest is most severe when the sun-spot area is the smallest, and from the theory of the sunspots it does not seem unnatural. It is well known that the changes in sun-spots are closely related to the changes in the atmospheric pressure and consequently in the rainfall; and experience shows that the development of the fungus is dependent to a great extent on the atmospheric conditions and rainfall. The opinions of the farmers put forward in the Second and Third Conferences indicate the same thing. Rust is usually most prevalent in seasons when the rainfall is excessive, especially during October and November. ${ }^{2}$ When close, damp, muggy weather sets in, the rust is certain to appear (indicating diminution in pressure). A dry cold season in Queensland is inimical to rust. The year 1889, which was a very rusty one, was marked in New South Wales by frequent thunderstorms at the time the wheat was in bloom. The colder districts were in that year less rusty than others.

The author states that when he thought the matter over, especially the remark by Dr. Prain, he thought there must be some relation between this eleven-year cycle and the Brookner's cycle of sunspots, which is also of eleven years, and that when he began to compare the two cycles closely, he was "almost convinced" that there must be some relation between sunspots and the growth of the Puccinia fungus. This relationship, he concludes, may "throw a great light on the life history of the fungus and also we may be able to foretell the years in which the rust attacks will

${ }^{2}$ Proc. of II. Con., 17, 49. 
be severe from the observation of the sunspots."

A hasty survey of the literature concerning the occurrence of Puccinia, and brief correspondence or personal conferences with some of our American botanists failed to reveal any knowledge of this hypothesis, and although it is not probable that it is of any great importance, I thought it would be of sufficient interest to be placed on record in an American publication. $\quad$ C. StUart Gager

Brooklyn Botanic Garden

\section{SPECIAL ARTICLES}

TIER-LIKE ARRANGEMENT OF THE ELEMENTS OF CERTAIN WOODS

There are numerous woods which present on longitudinal section (particularly the tangential) fine, delicate cross lines or stripes sometimes called "ripple marks." The distance between these markings varies from 0.11 to $0.50 \mathrm{~mm}$., and is fairly constant for a species. On some woods (e. g., 'Atsculus octandra Marsh., Swietenia mahagoni Jacq., Bombax insigne Wall. and Pterospermum diversifolium Blume.) these lines are very clear and distinct to the unaided eye; on others (e. g., Tilia americana L., T. pubescens Ait., Pterocarpus indicus Willd. and P. dalbergioides Roxb.) they are near the limit of vision or again (e. g., Guaiacum sanctum L. and $G$. officinale L.) they are invisible without the lens. In most species showing these markings the feature is constant and of considerable importance for diagnostic purposes, though in a few species (e. g., Swietenia mahagoni) the same piece of wood may show the markings in one place and not in another.

This cross-striping of a wood is due (1) to the arrangement of the rays in horizontal series, or (2) to the tier-like ranking of the wood fibers, vessel segments or other elements, or (3) to a combination of (1) and (2). The lines resulting from the horizontal seriation of the rays is usually more conspicuous and of more common occurrence than those in (2). In the combination of the two forms, which is very common, the junction of the vessel segments or of the fibers is usually between the rays.

This peculiar arrangement of wood elements is also evidenced on transverse section. Where the rays are in perfect horizontal seriation a section between two tiers shows an entire absence of rays. In most instances, however, it results in gaps of irregular width depending upon the regularity of the stories. Where the rays are much wider near the middle than at the margin their apparent width when viewed transversely will show considerable variation, according to the relative location of the plane of section. Where the fibers are arranged in tiers their apparent size is affected in a similar manner. According to von Höhnel ${ }^{1}$ the fibers in Bocoa provacensis Aubl., and a few other tropical woods with cross-striping are also radially disposed, and when the plane of cutting passes near the junction of two tiers the section shows large and small cells in alternate radial rows. The small cells are sections of the tips of the fibers forced by growth between their upper and lower neighbors. It is von Höhnel's theory that their appearance in alternate radial rows instead of alternately in the same row is the result of the pressure of the bark upon the cambium while the fibers were being formed.

Tier-like arrangement is most common in tropical woods and has been found fairly characteristic of the families Cæsalpiniaceæ and Zygophyllaceæ. Various writers ${ }^{2}$ have

${ }^{1}$ Von Höhnel, Franz Ritter, "Ueber stockwerkartig aufgebaute Holzkörper,' Sitzungsberichte der Mathematische-Naturwissenschaftlichen Classe der kaiserlichen Akademie der Wissenschaften, Vol. 89, Part 1, Wien, 1884, pp. 30-47. Von Höhnel, Franz Ritter, " Ueber den etagenformigen Aufbau einiger Holzkörper,', Berichte der Deutschen Botanischen. Gesellschaft, Vol. II., Berlin, 1884, pp. 2-5.

${ }^{2}$ Flückinger, J. A., "Pharmacognosie der Pflanzen,' 2d ed., pp. 463, 466. Wigand, A., "Anatomische Atlas zur pharmaceutischem Werkende," 1865, tables 26, 27. Whitford, H. N., "The Forests of the Philippines," Bul. 10, Bureau of Forestry, Manila, P. I., 1911, Vol. II., p. 36. 